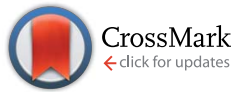

Cite this: RSC Adv., 2017, 7, 13971

Received 2nd January 2017

Accepted 24th February 2017

DOI: $10.1039 / \mathrm{c} 7 \mathrm{ra00044h}$

rsc.li/rsc-advances

\section{Carbon supported Rh nanoparticles for the production of hydrogen and chemicals by the electroreforming of biomass-derived alcohols $\uparrow$}

\author{
Maria Vincenza Pagliaro, ${ }^{\text {ab }}$ Marco Bellini, ${ }^{a}$ Manuela Bevilacqua, ${ }^{a}{ }^{2}$ onathan Filippi, ${ }^{a}$ \\ Maria Gelsomina Folliero, ${ }^{\text {ab }}$ Andrea Marchionni, ${ }^{a}$ Hamish Andrew Miller, ${ }^{* a}$ \\ Werner Oberhauser, ${ }^{a}$ Stefano Caporali, ${ }^{c d}$ Massimo Innocenti ${ }^{\text {ae }}$ and Francesco Vizza ${ }^{* a}$
}

Electroreforming is a low energy cost technology that combines the production of valuable chemicals from biomass-derived alcohols with the evolution of clean hydrogen at low temperature and atmospheric pressure. The selectivity for the desired chemicals is governed by the nature of the anode catalyst. Here we report the synthesis and characterization of a carbon supported nanostructured Rh electrocatalyst. The Rh nanoparticles are shown to be highly dispersed $(2.2 \mathrm{~nm})$ and a complete electrochemical study is reported. This Rh/C catalyst exhibits high activity for alcohol electrooxidation (e.g. $5700 \mathrm{~A} \mathrm{~g}_{\mathrm{Rh}}$ for $\mathrm{EG}$ at $80{ }^{\circ} \mathrm{C}$ ) and when employed with an anion exchange membrane and $\mathrm{Pt} / \mathrm{C}$ cathode in an electroreformer produces high volumes of hydrogen at low electrical energy input (e.g. $500 \mathrm{~mA} \mathrm{~cm}{ }^{-2}$ at $0.7 \mathrm{~V}_{\text {cell }}$ and $E_{\text {cost }}=9.6 \mathrm{~kW} \mathrm{~h} \mathrm{~kg}_{2}{ }^{-1}$ ). A complete analysis of the alcohol oxidation products from several renewable alcohols (ethanol, ethylene glycol, glycerol and 1,2-propandiol) shows a selectivity in the formation of valuable chemicals such as lactate and glycolate.

\section{Introduction}

Water electrolysis is the most popular alternative to the production of hydrogen from fossil fuels as it is the only route that permits the use of renewable (e.g., photovoltaic, wind, biomass, geothermal) energy sources combined with the production of $99.999 \%$ pure hydrogen..$^{1-3}$ Currently, only a small proportion of the world's hydrogen production (circa 4\%) comes from electrolytic water splitting. ${ }^{1}$ In fact, although water electrolysis is a well-known and consolidated process it does not have a significant commercial impact owing to its high-energy consumption, which, ultimately, makes it economically unattractive. The U.S. Department of Energy (DOE) has highlighted this drawback. Indeed, in 2011, the DOE has set a target that the electrical energy input to an electrolyzer stack should drop from 45 to $43 \mathrm{~kW} \mathrm{~h} \mathrm{~kg}^{-1} \mathrm{H}_{2}$ by $2020 .^{4}$

The three most common low temperature water electrolysis technologies may be categorized as follows; ${ }^{5}$

${ }^{a}$ CNR-ICCOM, via Madonna del Piano 10, 50019, Sesto Fiorentino (FI), Italy. E-mail: francesco.vizza@iccom.cnr.it

${ }^{b}$ Università di Siena, Dipartimento di Biotecnologie, Chimica e Farmacia, via Aldo Moro 2, Siena 53100, Italy

${ }^{c}$ Consorzio INSTM, Via Giusti 9, 50121 Firenze, Italy

${ }^{d}$ CNR-ISC, via Madonna del Piano 10, 50019, Sesto Fiorentino (FI), Italy

${ }^{e}$ Dipartimento di Chimica, Università di Firenze, via della Lastruccia 3, 50019 Sesto Fiorentino (FI), Italy

$\dagger$ Electronic supplementary information (ESI) available. See DOI: 10.1039/c7ra00044h (i) Alkaline electrolysis with a liquid alkaline electrolyte (typically aqueous $\mathrm{KOH}$ ).

(ii) Zero gap or advanced alkaline configuration.

(iii) Acidic PEM electrolysis with a proton-conducting polymer electrolyte membrane.

In alkaline electrolyte, water electrolysis proceeds as follows:

Anode reaction: $2 \mathrm{OH}^{-} \rightarrow \frac{1}{2} \mathrm{O}_{2}+\mathrm{H}_{2} \mathrm{O}+2 \mathrm{e}^{-} \quad E_{\mathrm{a}}^{0}=0.404 \mathrm{~V}$

Cathode reaction: $2 \mathrm{H}_{2} \mathrm{O}+2 \mathrm{e}^{-} \rightarrow \mathrm{H}_{2}+2 \mathrm{OH}^{-} \quad E_{\mathrm{c}}^{0}=-0.826 \mathrm{~V}$

In acid electrolyte:

Anode reaction: $\mathrm{H}_{2} \mathrm{O} \rightarrow \frac{1}{2} \mathrm{O}_{2}+2 \mathrm{H}^{+}+2 \mathrm{e}^{-} \quad E_{\mathrm{a}}^{0}=1.23 \mathrm{~V}$

Cathode reaction: $2 \mathrm{H}^{+}+2 \mathrm{e}^{-} \rightarrow \mathrm{H}_{2} \quad E_{\mathrm{c}}^{0}=0.0 \mathrm{~V}$

The standard reaction potential for water splitting is $1.23 \mathrm{~V}$, meaning that the process is thermodynamically a nonspontaneous reaction. In practice, to get electrolysis current densities in the range of 1-2 $\mathrm{A} \mathrm{cm}^{-2}$ the electrolysis cell potential usually ranges between 1.6 and $2 \mathrm{~V}^{6}{ }^{6}$ Using $1.8 \mathrm{~V}$ as a reasonable value, we can calculate that $68.3 \%$ of the energy input is consumed by overcoming thermodynamics, while 
kinetic factors account for only $31.7 \%$. Replacing anodic oxygen evolution with the oxidation of much more readily oxidizable species leads to a significant reduction of the potential required to produce hydrogen. Researchers have demonstrated that this strategy works using so-called sacrificial compounds such as ammonia, ${ }^{7,8}$ methanol, ${ }^{9}$ ethanol, ${ }^{10-13}$ glycerol ${ }^{11,12,14,15}$ and urea. ${ }^{16}$ This electrolysis technology combining the oxidation of such substrates with the generation of hydrogen at the cathode are often indicated as "Electrochemical Reforming" or "electroreforming". Electrolysis occurs at cell potentials lower than $1 \mathrm{~V}$, leading to electrical power savings as compared to conventional electrolytic water splitting. Renewable biomass derived alcohols are attractive substrates for application in electrochemical reforming due to their low toxicity and their potential as part of carbon neutral energy transformation processes. ${ }^{17,18}$ Included in this group are ethylene glycol ${ }^{19,20}(\mathrm{EG})$ and glycerol $^{\mathbf{2 1 , 2 2}}(\mathrm{G})$. Ethylene glycol has a volumetric energy density of $5.9 \mathrm{~kW} \mathrm{~h} \mathrm{~L} \mathrm{~L}^{-1}$ and can be produced by the heterogeneous hydrogenation of cellulose derivatives. ${ }^{23,24}$ Glycerol has a volumetric energy density of $6.3 \mathrm{~kW} \mathrm{~h} \mathrm{~L}{ }^{-1}$, and is a by-product of biodiesel production and, as such, is inexpensive ( $\left.0.3 \mathrm{USS} \mathrm{kg}^{-1}\right)$ and readily available (2.4 million tonnes produced per year). ${ }^{25}$

Eqn (5)-(7) describe the anode, cathode and overall electrochemical reforming reactions and standard electrode potentials (RHE) respectively for ethanol under alkaline conditions. With ethanol as fuel, the standard reaction potential for hydrogen production is $0.106 \mathrm{~V}$. Therefore, hydrogen evolution is much more favorable when compared to water electrolysis where the standard potential is $1.23 \mathrm{~V}$ (RHE).

$$
\begin{gathered}
\mathrm{CH}_{3} \mathrm{CH}_{2} \mathrm{OH}+5 \mathrm{OH}^{-} \rightarrow \mathrm{CH}_{3} \mathrm{COO}^{-}+4 \mathrm{e}^{-}+4 \mathrm{H}_{2} \mathrm{O} \\
E_{\mathrm{a}}^{0}=-0.72 \mathrm{~V} \\
4 \mathrm{H}_{2} \mathrm{O}+4 \mathrm{e}^{-} \rightarrow 2 \mathrm{H}_{2}+4 \mathrm{OH}^{-} \quad E_{\mathrm{c}}^{0}=-0.826 \mathrm{~V} \\
\mathrm{CH}_{3} \mathrm{CH}_{2} \mathrm{OH}+\mathrm{OH}^{-} \rightarrow \mathrm{CH}_{3} \mathrm{COO}^{-}+2 \mathrm{H}_{2} \quad E_{\text {tot }}^{0}=0.106 \mathrm{~V}
\end{gathered}
$$

Other poly-alcohols can be oxidized provide not only hydrogen but also valuable chemicals from the formation of partially oxidized intermediates. ${ }^{26-29}$ For example, 1,2-propandiol can be employed in electroreforming to produce lactate, an industrially relevant chemical. ${ }^{30-33}$

The efficiency of an electrolyzer is directly related to the electrode materials, in particular to the catalysts deposited onto the surface of the electrodes. The function of these catalysts is to reduce the activation energy for both the anode and cathode reactions. Therefore, a crucial role in improving the effective energetic efficiency of an electrolyzer is played by the electrode materials, because they determine both the energy consumption (at a given reaction rate) and the maximum reaction rate in the cell.

In this paper, we report an electroreformer that couples the partial oxidation of renewable alcohols with hydrogen evolution for the simultaneous and sustainable production of carboxylic compounds and high-purity hydrogen. The electroreformer is assembled with an anode containing nanostructured $\mathrm{Rh} / \mathrm{C}$ electrocatalyst. This catalyst is composed of highly dispersed Rh nanoparticles supported on carbon, which shows high activity for alcohol electrooxidation. The employment of this catalyst enables high hydrogen production levels at very low energy cost. The paper also reports a net energy analysis of hydrogen production using bio-ethanol (as example) in order to clearly demonstrate the potential of electroreforming technology.

\section{Experimental}

\section{Materials}

Carbon black (Vulcan XC-72) was purchased from Cabot Corp., USA. The alkaline anion exchange membrane used was the A201 obtained from Tokuyama Corp. (Japan). All metal salts and reagents were purchased from Aldrich and used without further purification. All the solutions were freshly prepared with doubly distilled deionized water.

\section{Synthesis of $\mathrm{Rh} / \mathrm{C}$ anode catalyst}

$3.8 \mathrm{~g}$ of carbon powder (Vulcan XC-72, Cabot corp., USA) was suspended in $640 \mathrm{~mL}$ of ethylene glycol and sonicated for $80 \mathrm{~min}$ in a $2 \mathrm{~L}$ round-bottomed flask. Then an aqueous solution of $\mathrm{H}_{2} \mathrm{O}(160 \mathrm{~mL})$ containing $740 \mathrm{mg}$ of dissolved $\mathrm{RhCl}_{3}$ $\cdot 6 \mathrm{H}_{2} \mathrm{O}$ (Aldrich), was added dropwise to the suspension under stirring. After this an alkaline solution of $\mathrm{NaOH}(15.8 \mathrm{~g})$ in $\mathrm{H}_{2} \mathrm{O}$ $(80 \mathrm{~mL})$ and ethylene glycol $(200 \mathrm{~mL})$ was introduced to the reactor which was then heated at $120{ }^{\circ} \mathrm{C}$ for $3 \mathrm{~h}$ under a $\mathrm{N}_{2}$ atmosphere, under vigorous stirring. The mixture was then cooled to room temperature and the solid product was filtered off and washed thoroughly with $\mathrm{H}_{2} \mathrm{O}$ to neutral $\mathrm{pH}$. The solid product thus obtained was dried under vacuum at $40{ }^{\circ} \mathrm{C}$. Yield $3.67 \mathrm{~g}$. ICP-AES analysis: Rh content $=6 \mathrm{wt} \%$ (ICP-AES).

\section{Physical characterization}

Transmission electron microscopy (TEM) was performed using a Philips CM12 microscope at an accelerating voltage of $100 \mathrm{kV}$. The microscope was equipped with an EDAX energy dispersive microanalysis system.

The BET surface area was determined using an ASAP 2020C Instrument (Micromeritics Corp.).

X-ray photoelectron Spectroscopy (XPS) measurements were performed in a system equipped with a VSW HAC 5000 hemispherical electron energy analyzer and a non-monochromated $\mathrm{Mg} \mathrm{K} \alpha$ X-ray source (1253.6 eV). Photoelectron spectra were acquired in the constant-pass-energy mode at $E_{\text {pas }}=44 \mathrm{eV}$, and the overall energy resolution was $1.2 \mathrm{eV}$ measured as a fullwidth at half maximum (FWHM) of the $\mathrm{Ag} 3 \mathrm{~d}_{5 / 2}$ line of a pure silver reference. The pressure during the experiment was kept below $2 \times 10^{-9}$ Torr. No neutralizer was utilized and the spectra energy scale was corrected using the $\mathrm{Au} 4 \mathrm{f}_{7 / 2}$ peak. The recorded spectra were fitted using XPS Peak 4.1 software. Gauss-Lorentz curves were used to fit the data after subtraction of a Shirleytype background.

\section{Electrochemical characterization}

The electrochemical measurements were performed using a Parstat 2273 potentiostat-galvanostat (Princeton Applied 
Research) equipped with a Model 616 rotating disk electrode RDE (PAR-Ametek). A $5 \mathrm{~mm}\left(A=0.1963 \mathrm{~cm}^{2}\right)$ Teflon-potted glassy-carbon disk electrode tip (PINETM) was used as substrate for the deposition of the catalyst ink. Before the deposition, the glassy-carbon surface was polished with different CT diamond suspension with a progressively smaller particle size $(1 \mu \mathrm{m}, 0.25 \mu \mathrm{m}, 0.1 \mu \mathrm{m})$ and finally washed with distilled water. The catalyst ink was prepared by mixing the $\mathrm{Rh} /$ $\mathrm{C}$ catalyst and distilled water in order to obtain $1 \mathrm{wt} \%$ suspension. The ink was sonicated for $1 \mathrm{~h}$ in a FALC sonicating bath to obtain a uniform suspension. The catalyst film was prepared by dispersing $8 \mu \mathrm{L}$ of the catalyst ink on the glassy-carbon electrode. The exact amount of dry catalyst deposited was determined using an analytical balance. The final Rh loading on the electrode was between 5 and $6 \mu \mathrm{g}\left(25-30 \mu \mathrm{g} \mathrm{cm}^{-2}\right)$. Each electrode was dried for $30 \mathrm{~min}$ before the addition of $2.5 \mu \mathrm{L}$ of a 0.4 wt\% Tokuyama ${ }^{\mathrm{TM}} \mathrm{OH}$-type anion exchange resin alcohol solution (AS4). After drying, the catalyst-ionomer coated disk was then mounted on the rotating disk electrode shaft and immersed into the electrolyte solution. The counter electrode was a platinum gauze enclosed in a glass tube with porous bottom.

The reference electrode used was commercial $\mathrm{Ag} / \mathrm{AgCl} / \mathrm{KCl}_{\text {sat }}$ (Princeton Applied Research). All cyclic voltammetry potentials are reported against reversible hydrogen electrode (RHE) calculated taking into account the potential-temperature dependence, as described in the ESI. $\dagger$ The electrochemical experiments were conducted at three temperatures $(25,60$ and $80{ }^{\circ} \mathrm{C}$ ). The $\mathrm{CV}$ experiments were undertaken in $2 \mathrm{M}$ aqueous $\mathrm{KOH}$ (Sigma-Aldrich, 99.8\%) while the alcohol electrooxidation studies were performed in aqueous solutions of $2 \mathrm{M} \mathrm{KOH}$ and $2 \mathrm{M}$ alcohol. All the solutions were prepared with Millipore water (18 $\mathrm{M} \Omega \mathrm{cm}^{-1}$ ) provided by a Milli-Q Labo apparatus (Nihon Millipore Ltd.). Solutions were deaerated by bubbling high-purity $\mathrm{N}_{2}$ for 30 min before each measurement.

CO stripping voltammograms were performed in aqueous $2 \mathrm{M} \mathrm{KOH}$. As first step, the $\mathrm{KOH}$ solution was saturated with bubbling CO for $20 \mathrm{~min}$, after which a fixed voltage of $70 \mathrm{mV}$ (RHE) was applied for 15 min to the working electrode to allow the complete adsorption of a monolayer of CO onto the surface of the catalyst. Then the excess CO in the electrolyte was purged out with bubbling $\mathrm{N}_{2}$ for $20 \mathrm{~min}$. The amount of $\mathrm{CO}_{\mathrm{ads}}$ was calculated integrating the respective stripping peak and the corresponding charge was used to extrapolate and calculate the ECSA of the $\mathrm{Rh} / \mathrm{C}$ catalyst.

\section{Electroreformer cell testing}

The MEAs (membrane electrode assemblies) prepared for the electroreformer cell consist of the $\mathrm{Rh} / \mathrm{C}$ catalyst as anode, a commercial Tokuyama A-201 anion-exchange membrane, and a commercial $40 \mathrm{wt} \% \mathrm{Pt} / \mathrm{C}$ catalyst (Aldrich) as cathode.

A dense anode ink was prepared by mixing the desired quantity of powdered catalyst $\mathrm{Rh} / \mathrm{C}$ with an aqueous dispersion of PTFE (60 wt\% PTFE dispersion in $\mathrm{H}_{2} \mathrm{O}$ obtained from Aldrich) and distilled water. The amount of PTFE added was 5 $\mathrm{wt} \%$ relative to the dry catalyst weight. The catalyst paste was applied uniformly to a porous nickel foam support (110 PPI
HZTYKJ from Heze Tianyu Technology Development Co., Ltd. dimensions $5 \mathrm{~cm}^{2}$ ). The cathodic ink was prepared in a $5 \mathrm{~mL}$ high density polyethylene vial, mixing $200 \mathrm{mg}$ of the commercial $\mathrm{Pt}(40 \mathrm{wt} \%) / \mathrm{C}$ in $450 \mathrm{mg}$ of distilled water, $790 \mathrm{mg}$ of 1-propanol and $1.56 \mathrm{~g}$ of the ionomer Nafion ${ }^{\circledR}$ (5 wt\% in 2-propanol). The mixture was suspended with three pulses of ultrasound, $20 \mathrm{~W}$ power at the frequency of $20 \mathrm{kHz}$ (Bandelin Sonor pulse UW 2200 SERIES). Finally this paste was spread onto a carbon cloth W1S1005 (CeTech Co. Ltd.) gas diffusion layer, with a Meyer rod (no. 150) obtaining a $0.4 \mathrm{mg} \mathrm{cm}^{-2} \mathrm{Pt}$ loading.

The electroreformer test cell fixture was purchased from Scribner-Associates (USA). The MEAs were assembled by mechanically pressing together the anode, cathode and membrane described above within the cell hardware. The cell temperature was regulated at $60{ }^{\circ} \mathrm{C}$ using a Scribner $805 \mathrm{e}$ fuel cell station. The aqueous fuel solution (30 $\mathrm{cc}$ of $2 \mathrm{M} \mathrm{KOH}$ and $2 \mathrm{M}$ alcohol) was delivered to the anode at $1 \mathrm{~mL} \mathrm{~min}^{-1}$. Voltage scans and galvanostatic experiments were carried out using an ARBIN BT-2000 5A 4-channel instrument. Polarization experiments were recorded by applying a linear voltage ramp with a $10 \mathrm{mV} \mathrm{s}^{-1}$ scan rate between 0.2 to $0.8 \mathrm{~V}$.

\section{Alcohol electrooxidation selectivity study}

Chronopotentiometry experiments were performed by applying a constant electrolysis current of $125 \mathrm{~mA}$ to the cell at $60^{\circ} \mathrm{C}$ until the voltage reached the cut off value of $0.65 \mathrm{~V}$. The hydrogen produced at the cathode was monitored by a Bronkhorst massspecific hydrogen-calibrated flowmeter. The fuel solutions after the constant current experiments were quantitatively and qualitatively analyzed by ${ }^{13} \mathrm{C}\left\{{ }^{1} \mathrm{H}\right\}$ NMR spectroscopy and HPLC. A UFLC Shimadzu Chromatograph equipped with refraction index detector (RID) was used; the column is a GRACE-Alltech OA-1000 Organic Acids $(300 \mathrm{~mm} \times 6.5 \mathrm{~mm})$, thermostated at $35{ }^{\circ} \mathrm{C}$. The eluent is $0.01 \mathrm{~N} \mathrm{H}_{2} \mathrm{SO}_{4}$; and the eluent flow is $0.8 \mathrm{~mL}$ $\min ^{-1}$. NMR spectra were acquired with a with a Bruker Advance DRX 400 spectrometer. Chemical shifts $(\delta)$ are reported in ppm relative to TMS $\left({ }^{1} \mathrm{H}\right.$ and ${ }^{13} \mathrm{C}$ NMR spectra). Deuterated solvents (Sigma-Aldrich) used for NMR measurements were dried with activated molecular sieves; 1,4-dioxane was used as internal standard for product quantification.

\section{Results and discussion}

\section{Catalyst synthesis and characterization}

The $\mathrm{Rh} / \mathrm{C}$ catalyst was prepared by electro-less reduction in aqueous media of Vulcan XC-72-impregnated with $\mathrm{RhCl}_{3}$ using ethylene glycol at $120{ }^{\circ} \mathrm{C}$ for $3 \mathrm{~h}$ under inert atmosphere. The morphology and distribution of the supported metal particles was evaluated by transmission electron microscopy (TEM in Fig. 1). The particle size distribution of the $\mathrm{Rh} / \mathrm{C}$ catalyst is also shown and has a mean diameter value of $2.2 \mathrm{~nm}$.

The crystalline structure of the catalyst was also investigated by X-ray powder diffraction (XRD). The XRD pattern (Fig. SI $\dagger$ ) does not reveal the presence of a metallic Rh phase, consistent with the formation of small nanoparticles of $\mathrm{Rh}$ in agreement 

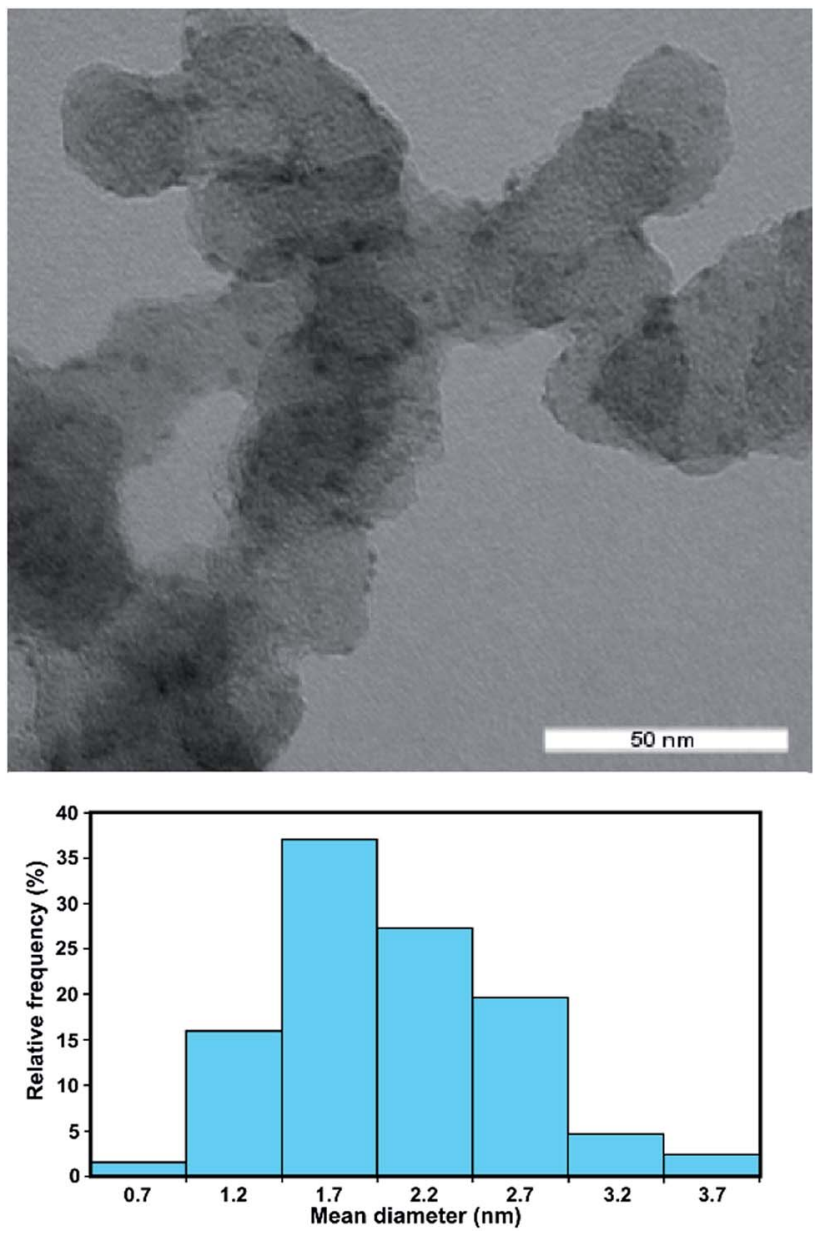

Fig. 1 TEM image and histogram of particle distribution versus diameter for $\mathrm{Rh} / \mathrm{C}$.

with the TEM analysis. The Brunauer-Emmett-Teller (BET) surface area was calculated as $195 \mathrm{~m}^{2} \mathrm{~g}^{-1}$.

The surface composition of the $\mathrm{Rh} / \mathrm{C}$ sample was also studied using X-ray photoelectron spectroscopy (XPS). The fitting of the data obtained shows the presence of three peaks (from the binding energy values) attributable to $\mathrm{Rh}(0) 307.3 \mathrm{eV}$, $\mathrm{Rh}_{2} \mathrm{O}_{3} 308.8 \mathrm{eV}$ (ref. 34-36) and a satellite peak of $\mathrm{Rh}_{2} \mathrm{O}_{3}$ $311.5 \mathrm{eV}$ (Fig. 2). The latter species was recently assigned by Boronin and coworkers. ${ }^{37}$ This analysis shows that rhodium oxide is the major component of the surface of the nanoparticles with Rh metal accounting for only around $35 \%$. Such a structure would lead to the XRD pattern that showed no visible trace for metallic Rh crystallites.

\section{Electrochemical properties}

The electrochemical activity of $\mathrm{Rh} / \mathrm{C}$ for alcohol electrooxidation was investigated by linear sweep voltammetry in electrochemical cells maintained at three different temperatures $\left(25,60\right.$ and $\left.80^{\circ} \mathrm{C}\right)$. For all experiments, the Rh loading on the glassy carbon substrate was between 25 and $35 \mu \mathrm{g}_{\mathrm{Rh}} \mathrm{cm}^{-2}$. We first studied the electrochemical behavior by cyclic voltammetry (CV) in $2 \mathrm{M} \mathrm{KOH}$ purged with $\mathrm{N}_{2}$ (Fig. 3).

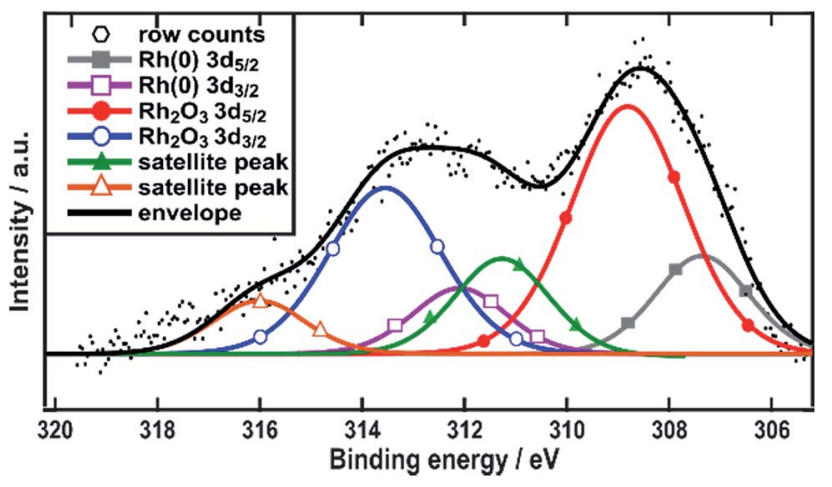

Fig. 2 XPS spectra in the $\mathrm{Rh} 3 \mathrm{~d}$ region. Spectra are referenced with respect to adventitious carbon at $284.8 \mathrm{eV}$.

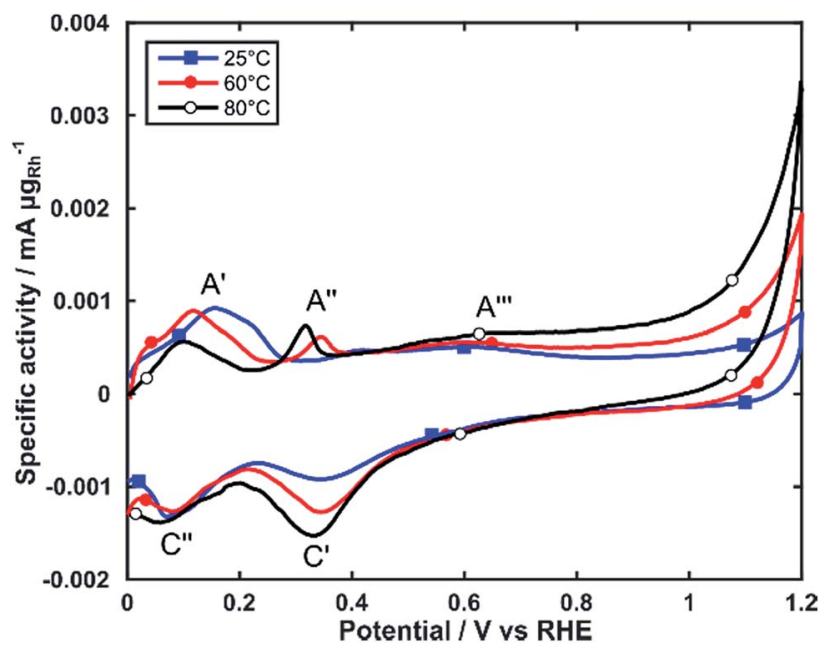

Fig. $3 \mathrm{CVs}$ of $\mathrm{Rh} / \mathrm{C}$ in $\mathrm{N}_{2}$ saturated $2 \mathrm{M} \mathrm{KOH}$. Scan rate: $10 \mathrm{mV} \mathrm{s}^{-1}$.

As reported in the literature the CV exhibits a number of anodic and cathodic transitions that can be assigned to $\mathrm{Rh}$ centered transitions..$^{38,39}$ On the positive potential scan ( 0 to $1.2 \mathrm{~V}$ ), peak $\mathrm{A}^{\prime}$ represents the oxidative desorption of hydrogen; peak $\mathrm{A}^{\prime \prime}$ relates to the formation of adsorbed $\mathrm{OH}$ species on the $\mathrm{Rh}$ nanoparticle surface and peak $\mathrm{A}^{\prime \prime \prime}$ is the onset of the formation of Rh oxide species. On the cathodic return scan peak $\mathrm{C}^{\prime}$ corresponds to the electroreduction of the oxide layer, and peak $\mathrm{C}^{\prime \prime}$ to the electrosorption of $\mathrm{H}$-adatoms.

CVs obtained at increasing temperatures $\left(60\right.$ and $\left.80^{\circ} \mathrm{C}\right)$ show significant changes to the intensity and potential of these transitions. Peak $\mathrm{A}^{\prime}$ shifts by approximately $0.1 \mathrm{~V}$ towards more negative potentials, while decreasing in intensity. Peak $\mathrm{A}^{\prime \prime}$ increases in intensity and shifts about $75 \mathrm{mV}$ towards more negative potentials. This behavior indicates an increased ability for the electrooxidation of alcohols, as it shows that $\mathrm{RhOH}_{\mathrm{ads}}$ species form at lower potentials $\left(\mathrm{A}^{\prime \prime}\right)$. The $\mathrm{RhOH}_{\text {ads }}$ species are those responsible for alcohol electrooxidation, analogously to the $\mathrm{PdOH}_{\mathrm{ads}}$ species formed onto palladium electrocatalysts, albeit formed at lower potential for Rh.

The electrochemically active surface area (ECSA) of the Rh nanoparticles was determined by integrating the charge of the 
electrooxidation peak of an adsorbed monolayer of $\mathrm{CO}_{\text {ads }}$ in $\mathrm{CO}$ stripping voltammograms (Fig. 4). ${ }^{40}$ The ECSA normalized by the mass of Rh was calculated as $75 \mathrm{~m}^{2} \mathrm{~g}_{\mathrm{Rh}}{ }^{-1}$.

The electrochemical activity of $\mathrm{Rh} / \mathrm{C}$ towards the oxidation of alcohols in alkaline media was investigated by cyclic voltammetry at $25{ }^{\circ} \mathrm{C}, 60^{\circ} \mathrm{C}$ and $80^{\circ} \mathrm{C}$, in degassed $2 \mathrm{M}$ aqueous $\mathrm{KOH}$ and $2 \mathrm{M}$ of either ethanol (EtOH), 1,2-propandiol (1,2-P), glycerol (G) or ethylene glycol (EG) (Fig. 5). Relevant electrochemical data is also listed in Table 1. In Fig. 5, we show the onset region (0.2-0.6 V RHE) of the forward scan for each alcohol at all three temperatures $\left(25,60\right.$ and $\left.80^{\circ} \mathrm{C}\right)$.

From Fig. 5 and Table 1, we can observe low oxidation onset potentials, which generally decrease as the temperature increases from $25{ }^{\circ} \mathrm{C}$ to $80{ }^{\circ} \mathrm{C}$, whereas the specific current densities dramatically increase with temperature for all alcohols, up to 35 times for EG. The intensity of the forward peaks in the CVs is determined by the progressive coverage of the $\mathrm{Rh}$ surface with oxide or partially oxidized poisoning species. In the complete CVs, (Fig. S2 $\dagger$ ) for ethanol a change of slope at $0.7 \mathrm{~V}$ is observed, caused by different adsorption types of ethanol on $\mathrm{Rh}^{{ }^{41}}$ The enhanced electrocatalytic activity observed at higher temperatures $\left(60-80{ }^{\circ} \mathrm{C}\right)$ can be ascribed to the accelerated kinetics of alcohols oxidation, which it is also favored by an

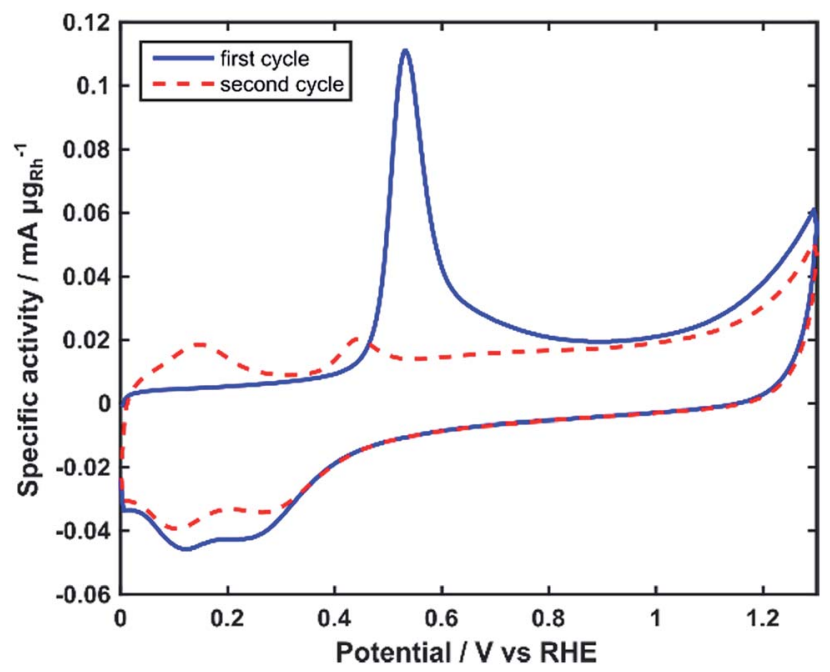

Fig. $4 \mathrm{CO}$-stripping voltammograms of $\mathrm{Rh} / \mathrm{C}$ in $2 \mathrm{M} \mathrm{KOH}$. Scan rate: $10 \mathrm{mV} \mathrm{s}^{-1}$. anticipated formation of $\mathrm{RhOH}_{\text {ads }}$ species at lower potentials as observed in Fig. 3.

\section{Electrochemical-reforming experiments}

Nickel foam $\left(5 \mathrm{~cm}^{2}\right)$ coated with Rh/C and using PTFE as binder was used as anode electrode $\left(1 \mathrm{mg}_{\mathrm{Rh}} \mathrm{cm}^{-2}\right)$ in the electroreformer (ER) cell equipped with an anion exchange membrane (Tokuyama A201) and a Pt/C on carbon cloth cathode $\left(0.4 \mathrm{mg}_{\mathrm{Pt}}\right.$ $\mathrm{cm}^{-2}$ ). The anode compartment of the cell was fed by recycling $30 \mathrm{~mL}$ of aqueous solutions of alcohol $2 \mathrm{M}$ and $2 \mathrm{M} \mathrm{KOH}$. At a cell temperature of $60{ }^{\circ} \mathrm{C}$ the performance was measured using potentiodynamic scans and galvanostatic experiments. For each alcohol, three batches of fuel were run consecutively in the same cell.

Polarization curves were obtained in the potential range from 0.2 to $0.7 \mathrm{~V}$ at $10 \mathrm{mVs}^{-1}$. Fig. $6 \mathrm{a}$ and Table 2 show that the electroreformer performs best with EtOH and EG reaching current densities of $492 \mathrm{~mA} \mathrm{~cm}{ }^{-2}$ and $416 \mathrm{~mA} \mathrm{~cm}{ }^{-2}$, respectively at a cell voltage of 0.7 . With the longer chain alcohols, 1,2$\mathrm{P}$ and $\mathrm{G}$, the current density obtained at $0.7 \mathrm{~V}$ were $367 \mathrm{~mA} \mathrm{~cm}^{-2}$ and $113 \mathrm{~mA} \mathrm{~cm}{ }^{-2}$ respectively.

In all cases, the cell performance was stable over the three batch experiments indicating no loss in performance during

Table 1 Relevant electrochemical parameters for alcohol electrooxidation at 25,60 and $80^{\circ} \mathrm{C}$ on electrodes coated with $\mathrm{Rh} / \mathrm{C}$

\begin{tabular}{llllll}
\hline Fuel & $T\left({ }^{\circ} \mathrm{C}\right)$ & $\begin{array}{l}E_{\text {onset }} \\
(\mathrm{V} v s . \text { RHE })\end{array}$ & $\begin{array}{l}E_{\text {forward peak }} \\
(\mathrm{V} v s . \text { RHE })\end{array}$ & $\begin{array}{l}J_{\text {peak }}{ }^{a} \\
\left(\mathrm{~mA} \mathrm{mg}_{\mathrm{Rh}}{ }^{-1}\right)\end{array}$ & $\begin{array}{l}J_{\text {peak/ECSA }}{ }^{b} \\
\left(\mathrm{~mA} \mathrm{~cm}^{-2}\right)\end{array}$ \\
\hline EtOH & 25 & 0.34 & 0.56 & 45 & 0.060 \\
$1,2-\mathrm{P}$ & 25 & 0.35 & 0.55 & 95 & 0.127 \\
EG & 25 & 0.33 & 0.59 & 167 & 0.223 \\
G & 25 & 0.46 & 0.57 & 103 & 0.137 \\
EtOH & 60 & 0.32 & 0.56 & 320 & 0.427 \\
1,2-P & 60 & 0.33 & 0.53 & 521 & 0.695 \\
EG & 60 & 0.32 & 0.57 & 2728 & 3.637 \\
G & 60 & 0.44 & 0.54 & 287 & 0.383 \\
EtOH & 80 & 0.30 & 0.59 & 500 & 0.667 \\
$1,2-P$ & 80 & 0.31 & 0.49 & 886 & 1.155 \\
EG & 80 & 0.28 & 0.57 & 5767 & 7.689 \\
G & 80 & 0.31 & 0.55 & 1839 & 2.452
\end{tabular}

${ }^{a}$ Current normalized on total Rh metal loading. ${ }^{b}$ Current normalized on Rh electrochemical surface area (ECSA) i.e. $75 \mathrm{~m}^{2} \mathrm{~g}_{\mathrm{Rh}}{ }^{-1}$.
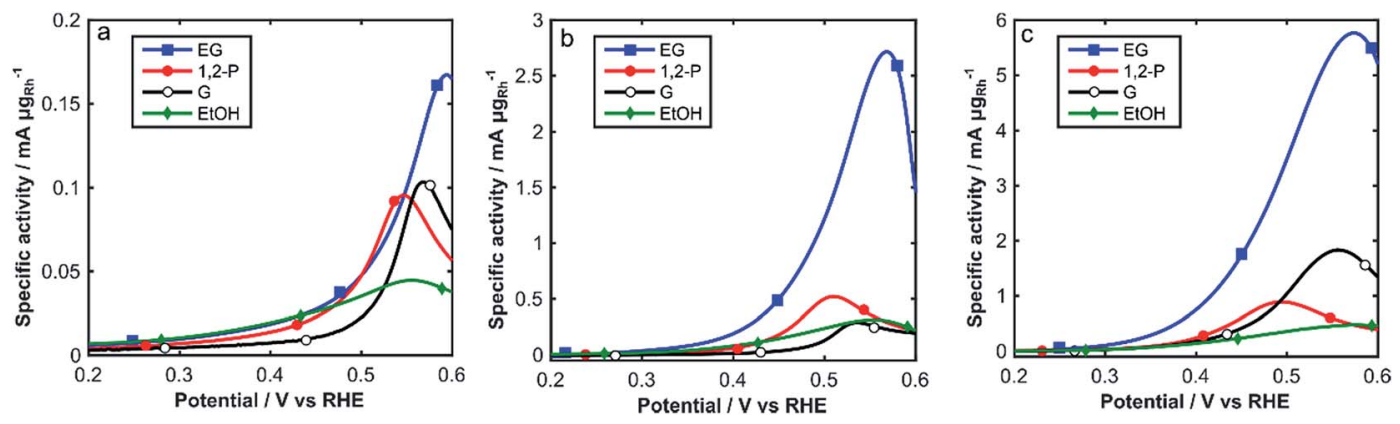

Fig. $5 \mathrm{CVs}$ of $\mathrm{Rh} / \mathrm{C}$ in $\mathrm{N}_{2}$ sat. $2 \mathrm{M} \mathrm{KOH}$ and $2 \mathrm{M}$ alcohol solutions: (a) $25^{\circ} \mathrm{C}$, (b) $60^{\circ} \mathrm{C}$ and (c) $80{ }^{\circ} \mathrm{C}(0.2-0.6 \mathrm{~V} \mathrm{RHE})$. Scan rate: $10 \mathrm{mV} \mathrm{s}$. 

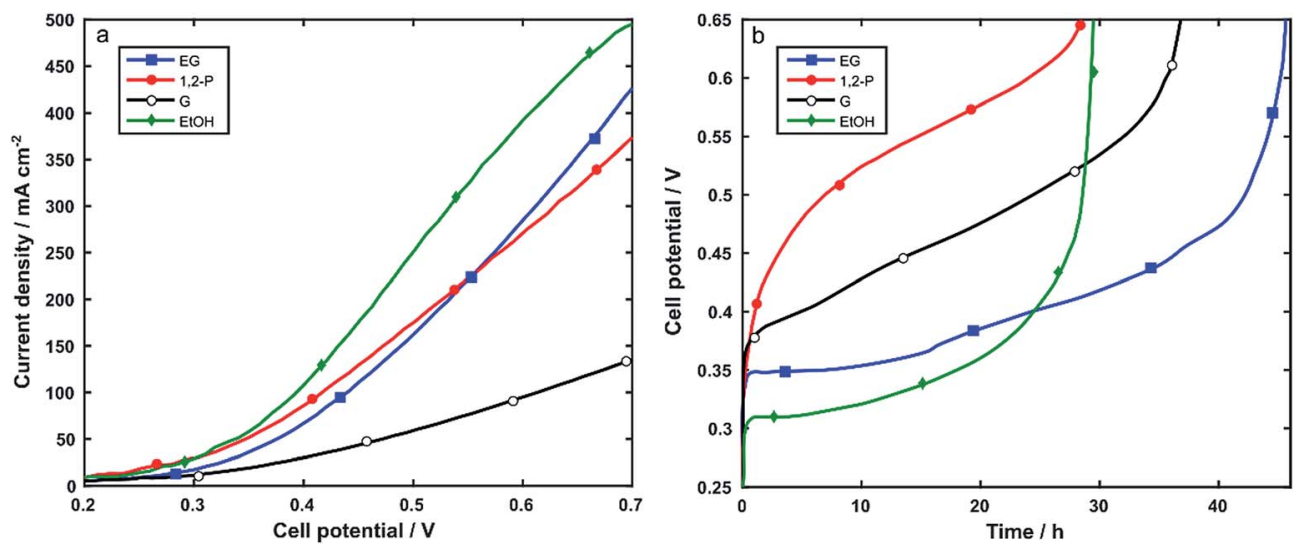

Fig. 6 (a) Potentiodynamic cycles of the electroreformer fueled with: $2 \mathrm{M}$ aqueous alcohol solutions in $2 \mathrm{M} \mathrm{KOH}$. Linear potential ramp, $10 \mathrm{mV}$ $\mathrm{s}^{-1}$. Cell temperature $60^{\circ} \mathrm{C}$; (b) galvanostatic curves at $125 \mathrm{~mA}$, fueled with $30 \mathrm{cc}$ of $2 \mathrm{M}$ aqueous alcohol solutions in $2 \mathrm{M} \mathrm{KOH}$. Cell temperature $60^{\circ} \mathrm{C}$.

Table 2 Catalytic data of electroreforming with $\mathrm{Rh} / \mathrm{C}$ at the anode at $60^{\circ} \mathrm{C}$

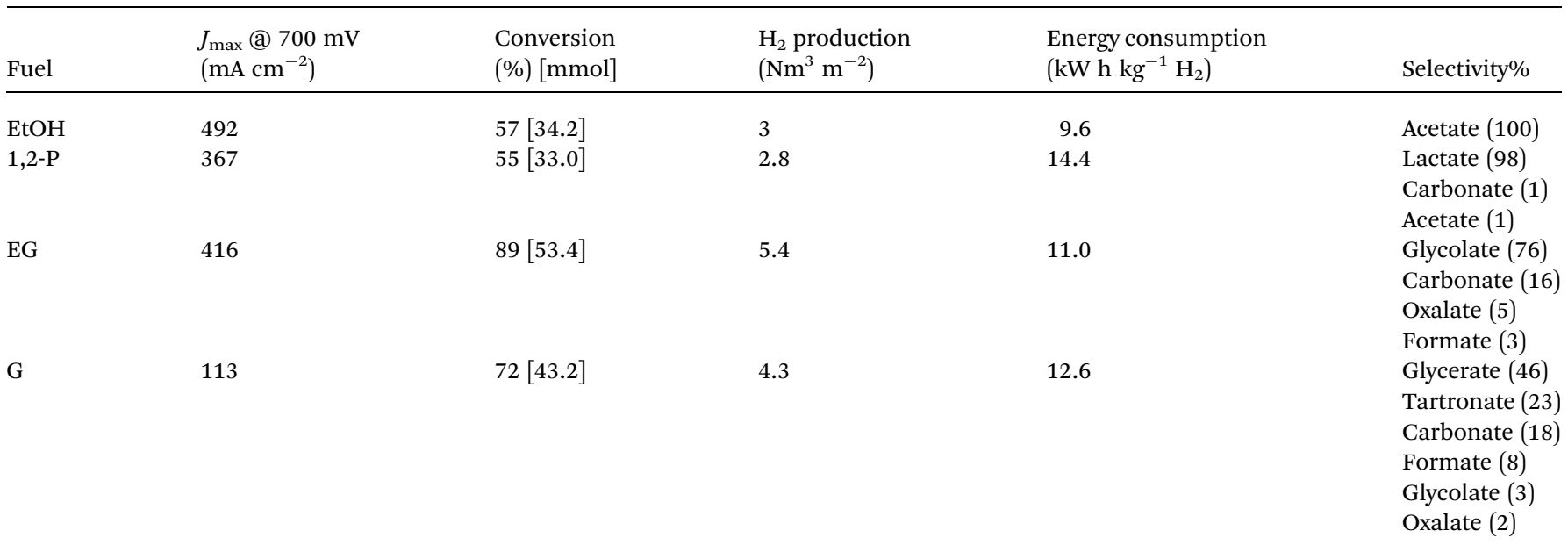

electrocatalysis. In order to study both the stability and the electrocatalytic activity over time as well as the electrooxidation product selectivity, the electroreformer was subjected to galvanostatic experiments where $30 \mathrm{~mL}$ of solutions of $2 \mathrm{M}$ alcohol and $2 \mathrm{M} \mathrm{KOH}$ were recycled at the anode electrode and the cell was set at a constant total current of $125 \mathrm{~mA}$. Each batch was stopped when the cell potential reached the value of $0.65 \mathrm{~V}$. The same set-up was run with three consecutive batches of fresh alcohol solutions. No decrease in activity was observed over the course of the three batches, indicating the stability of the catalyst over time. Fig. $6 \mathrm{~b}$ and Table 2 summarize the data obtained at $60{ }^{\circ} \mathrm{C}$.

The fuel exhausts were quantitatively and qualitatively analyzed by ${ }^{13} \mathrm{C}\left\{{ }^{1} \mathrm{H}\right\}$ NMR spectroscopy and HPLC. The results summarized in Table 2 show the fuel conversion and the distribution of the oxidation products identified and quantified by NMR and HPLC analysis.

With ethanol, the only product obtained is acetate with no evidence of $\mathrm{C}-\mathrm{C}$ bond breaking and formation of carbonate. The cells fed with EG and 1,2-P yielded circa 76\% glycolate and 98\% of lactate, respectively. Glycerol oxidation leads to significant $\mathrm{C}-\mathrm{C}$ bond scission, resulting in a mixture of products including glycerate, tartronate and also oxalate, glycolate, formate and carbonate, all from $\mathrm{C}-\mathrm{C}$ bond breaking reactions. No trace of the secondary alcohol oxidation products of $\mathrm{G}$ such as dihydroxyacetone, hydroxypiruvate, or mesoxalate was observed. As expected, at the cell working potentials no oxygen evolution at the anode was detected.

The amount of hydrogen evolved during each experiment was calculated from the number of moles of electrons exchanged in the electroreformer (see ESI $\dagger$ ) and measured experimentally with an hydrogen-calibrated flowmeter; the values were consistent indicating a $100 \%$ faradaic efficiency for the cathodic process. The energy consumption was then evaluated from the integration of the instantaneous charging power over the experimental duration time. This value, expressed in $\mathrm{kW} \mathrm{h}$, is reported with respect to the amount of hydrogen produced in kilograms (i.e. $\mathrm{kW} \mathrm{h} \mathrm{kg}_{\mathrm{H}_{2}}{ }^{-1}$ ). Table 2 shows that the amount of electrical energy required for $\mathrm{H}_{2}$ production for all alcohols is in the range of $10-14 \mathrm{~kW} \mathrm{~h} \mathrm{~kg}_{\mathrm{H}_{2}}{ }^{-1}$. 
Our recent reports of alcohol electroreforming with Pd based anode catalysts showed electrical energy consumption for the same levels (i.e. same current density) of $\mathrm{H}_{2}$ production in the region of $18-24 \mathrm{~kW} \mathrm{~h} \mathrm{~kg}^{-1} \cdot{ }^{30,31}$ Hence, the use of $\mathrm{Rh} / \mathrm{C}$ as anode catalyst significantly reduces the energy cost of electroreforming. In particular, we can calculate that the use of ethanol (9.6 $\mathrm{kW} \mathrm{h} \mathrm{kg}^{-1} \mathrm{H}_{2}$ ) results in an electrical energy saving of 35.4 $\mathrm{kW} \mathrm{h} \mathrm{kg}{ }^{-1} \mathrm{H}_{2}$ as compared with that reported by the DOE for PEM water electrolyzer stacks as of $2011\left(45 \mathrm{~kW} \mathrm{~h} \mathrm{~kg}^{-1} \mathrm{H}_{2}\right) .{ }^{4}$ The reason of this drop in energy consumption is due to the lower operating potentials for alcohol electrooxidation caused by the cathodic shift of the onset of the formation of $\mathrm{RhOH}_{\mathrm{ads}}$ species, that are responsible for the alcohol electrooxidation process itself.

One may now consider if from an overall energetic point of view the exploitation of alcohols such as ethanol for hydrogen production by electroreforming is actually worthy of consideration. According to the DOE the output energy density for bioethanol is $7.4 \mathrm{~kW} \mathrm{~h} \mathrm{~kg}_{\mathrm{EtOH}}{ }^{-1}$. From our calculations reported in the SI, we conclude that the production of bioethanol with an Energy Return of the Energy Invested (EROEI) larger than 3.1 is required in order to obtain a net energy saving with respect to current water electrolysis technology $\left(47 \mathrm{~kW} \mathrm{~h} \mathrm{~kg}^{-1} \mathrm{H}_{2}\right.$ ). The DOE target for electrolyzer stack electric energy input for $2020,{ }^{4}$ $43 \mathrm{~kW} \mathrm{~h} \mathrm{~kg}{ }^{-1} \mathrm{H}_{2}$, is instead met for a bio-ethanol EROEI larger than 3.6. Hence, hydrogen production by the electroreforming of bio-ethanol is energetically convenient depending on the production source of the alcohol e.g. using sugarcane that is commonly reported to have an EROEI of 8 and higher ${ }^{42}$ from cellulose with an EROEI potentially up to 35 depending on production methods. ${ }^{43}$

\section{Conclusions}

In this paper, examples of electrooxidation of biomass-derived alcohols such as EtOH, EG, G and 1,2-P have been studied in an electroreformer containing $\mathrm{Rh}$ nanoparticles supported on carbon as the anode electrocatalyst, equipped with an anion exchange membrane and a Pt/C on carbon cloth cathode. The oxidation of alcohols was first investigated in electrochemical half-cells at room temperature and at $60-80{ }^{\circ} \mathrm{C}$ in alkaline media. The results highlighted the excellent activity of $\mathrm{Rh} / \mathrm{C}$ in terms of peak current densities (as high as $5700 \mathrm{~A} \mathrm{~g}_{\mathrm{Rh}}{ }^{-1}$ for EG at $80{ }^{\circ} \mathrm{C}$ ) and low onset of potentials.

When employed as anode catalyst in electroreformer cells high current densities were obtained at cell potential well below $1 \mathrm{~V}$, resulting in significant energy saving when compared to traditional water electrolyzers. The amount of electrical energy required for $\mathrm{H}_{2}$ production for all alcohols is in the range of 10$14 \mathrm{~kW} \mathrm{~h} \mathrm{kg_{ \textrm {H } _ { 2 } }}{ }^{-1}$. These values are the lowest compared to those reported up to now in the literature. In particular, $9.6 \mathrm{~kW} \mathrm{~h}$ $\mathrm{kg}_{\mathrm{H}_{2}}{ }^{-1}$ from EtOH results in an electrical energy saving of 35.4 $\mathrm{kW} \mathrm{h} \mathrm{kg}_{\mathrm{H}_{2}}{ }^{-1}$ as compared with that reported by the DOE for PEM electrolyzer.

In terms of oxidation product selectivity, this $\mathrm{Rh} / \mathrm{C}$ catalyst was selective for EtOH electrooxidation to acetate (100\%) and 1,2-P oxidation to lactate (98\%). From EG and G a more complex mixture of partial oxidation products was obtained. In summary, the electroreformer reported in this paper provides not only hydrogen production but also valuable chemicals from the large variety of products that can be obtained by the electrooxidation of renewable alcohols. The remarkable electrocatalytic activity of $\mathrm{Rh} / \mathrm{C}$ employed as anode catalyst can be attributed to both the high dispersion of the metal nanoparticles as well as the intrinsic properties of nanostructured metallic Rh that shows low onset potentials for alcohol electrooxidation in half cells and low cell working potential during electroreforming.

\section{Acknowledgements}

We gratefully acknowledge the Ente Cassa di Risparmio di Firenze for the project EnergyLab and Hydrolab 2.0.

\section{References}

1 J. Mergel, M. Carmo and D. Fritz, Transition Renewable Energy Syst., 2013, 425-450, DOI: 10.1002/9783527673872.

2 A. Ursua, L. M. Gandia and P. Sanchis, Proc. IEEE, 2012, 100, 410-426.

3 J. A. Turner, Science, 2004, 305, 972-974.

4 Fuel Cell Technologies Office, Fuel cells, Fuel Cell Technologies Office Multi-year Research, Development and Demonstration Plan of the US Department of Energy, 2011.

5 S. Marini, P. Salvi, P. Nelli, R. Pesenti, M. Villa, M. Berrettoni, G. Zangari and Y. Kiros, Electrochim. Acta, 2012, 82, 384-391.

6 M. Carmo, D. L. Fritz, J. Merge and D. Stolten, Int. J. Hydrogen Energy, 2013, 38, 4901-4934.

7 M. Schalenbach, M. Carmo, D. L. Fritz, J. Mergel and D. Stolten, Int. J. Hydrogen Energy, 2013, 38, 14921-14933.

8 F. Vitse, M. Cooper and G. G. Botte, J. Power Sources, 2005, 142, 18-26.

9 T. Take, K. Tsurutani and M. Umeda, J. Power Sources, 2007, 164, 9-16.

10 C. Lamy, T. Jaubert, S. Baranton and C. Coutanceau, J. Power Sources, 2014, 245, 927-936.

11 V. Bambagioni, M. Bevilacqua, C. Bianchini, J. Filippi, A. Lavacchi, A. Marchionni, F. Vizza and P. K. Shen, ChemSusChem, 2010, 3, 851-855.

12 A. Caravaca, F. M. Sapountzi, A. de Lucas-Consuegra, C. Molina-Mora, F. Dorado and J. L. Valverde, Int. J. Hydrogen Energy, 2012, 37, 9504-9513.

13 A. Caravaca, A. de Lucas-Consuegra, A. B. Calcerrada, J. Lobato, J. L. Valverde and F. Dorado, Appl. Catal., B, 2013, 134, 302-309.

14 A. T. Marshall and R. G. Haverkamp, Int. J. Hydrogen Energy, 2008, 33, 4649-4654.

15 S. Kongjao, S. Damronglerd and M. Hunsom, J. Appl. Electrochem., 2011, 41, 215-222.

16 W. Yan, D. Wang and G. G. Botte, Appl. Catal., B, 2012, 127, 221-226.

17 A. Brouzgou, A. Podias and P. Tsiakaras, J. Appl. Electrochem., 2013, 43, 119-136. 
18 E. H. Yu, U. Krewer and K. Scott, Energies, 2010, 3, 14991528.

19 V. Livshits, A. Philosoph and E. Peled, J. Power Sources, 2008, 178, 687-691.

20 D. Kaplan, L. Burstein, Y. Rosenberg and E. Peled, J. Power Sources, 2011, 196, 8286-8292.

21 L. Xin, Z. Y. Zhang, Z. C. Wang and W. Z. Li, ChemCatChem, 2012, 4, 1105-1114.

22 A. Marchionni, M. Bevilacqua, C. Bianchini, Y. X. Chen, J. Filippi, P. Fornasiero, A. Lavacchi, H. Miller, L. Q. Wang and F. Vizza, ChemSusChem, 2013, 6, 518-528.

23 N. Ji, T. Zhang, M. Y. Zheng, A. Q. Wang, H. Wang, X. D. Wang and J. G. G. Chen, Angew. Chem., Int. Ed., 2008, 47, 8510-8513.

24 M. Y. Zheng, A. Q. Wang, N. Ji, J. F. Pang, X. D. Wang and T. Zhang, ChemSusChem, 2010, 3, 63-66.

25 J. Van Gerpen, Fuel Process. Technol., 2005, 86, 1097-1107.

26 V. Bambagioni, M. Bevilacqua, C. Bianchini, J. Filippi, A. Lavacchi, A. Marchionni, F. Vizza and P. K. Shen, ChemSusChem, 2010, 3, 851-855.

$27 \mathrm{~J}$. de Paula, D. Nascimento and J. Linares, J. Appl. Electrochem., 2015, 45, 689-700.

28 S. Gonzalez-Cobos, S. Baranton and C. Coutanceau, ChemElectroChem, 2016, 3, 1694-1709.

29 Z. Y. Zhang, L. Xin, J. Qi, D. J. Chadderdon, K. Sun, K. M. Warsko and W. Z. Li, Appl. Catal., B, 2014, 147, 871878.

30 Y. X. Chen, A. Lavacchi, H. A. Miller, M. Bevilacqua, J. Filippi, M. Innocenti, A. Marchionni, W. Oberhauser, L. Wang and F. Vizza, Nat. Commun., 2014, 5, 4036-4041.
$31 \mathrm{H}$. A. Miller, M. Bellini, F. Vizza, C. Hasenohrl and R. D. Tilley, Catal. Sci. Technol., 2016, 6, 6870-6878.

32 D. J. Chadderdon, L. Xin, J. Qi, B. Brady, J. A. Miller, K. Sun, M. J. Janik and W. Z. Li, ACS Catal., 2015, 5, 6926-6936.

33 M. Bellini, M. Bevilacqua, J. Filippi, A. Lavacchi, A. Marchionni, H. A. Miller, W. Oberhauser, F. Vizza, S. P. Annen and H. Grutzmacher, ChemSusChem, 2014, 7, 2432-2435.

34 M. H. M. T. Assumpção, R. M. Piasentin, P. Hammer, R. F. B. De Souza, G. S. Buzzo, M. C. Santos, E. V. Spinacé, A. O. Neto and J. C. M. Silva, Appl. Catal., B, 2015, 174-175, 136-144.

35 Q. He, S. Mukerjee, B. Shyam, D. Ramaker, S. ParresEsclapez, M. J. Illán-Gómez and A. Bueno-López, J. Power Sources, 2009, 193, 408-415.

36 M. A. Montero, J. L. Fernández, M. R. Gennero de Chialvo and A. C. Chialvo, J. Power Sources, 2014, 254, 218-223.

37 L. S. Kibis, A. I. Stadnichenko, S. V. Koscheev, V. I. Zaikovskii and A. I. Boronin, J. Phys. Chem. C, 2016, 120, 19142-19150.

38 Z. Cataldi, R. O. Lezna, M. C. Giordano and A. J. Arvia, J. Electroanal. Chem. Interfacial Electrochem., 1989, 261, 61-75.

39 M. Łukaszewski, H. Siwek and A. Czerwiński, Electrochim. Acta, 2007, 52, 4560-4565.

40 M. A. Montero, M. R. Gennero de Chialvo and A. C. Chialvo, J. Power Sources, 2015, 283, 181-186.

41 S. Y. Shen, T. S. Zhao and J. B. Xu, Int. J. Hydrogen Energy, 2010, 35, 12911-12917.

42 J. Goldemberg, Science, 2007, 315, 808-810.

43 C. A. S. Hall, B. E. Dale and D. Pimentel, Sustainability, 2011, 3, 2413-2432. 